\title{
Vulnerability of Ancient Dry-joint Masonry Towers
}

\author{
Funda Gençer ${ }^{1 *}$, Mine Hamamcıoğlu-Turan², Hasan Engin Duran³, Engin Aktaş \\ ${ }^{1}$ Department of Architecture, Faculty of Fine Arts, Design and Architecture, Manisa Celal Bayar University, 45140 Manisa, \\ Şehzadeler, Halil Erdoğan Street, Turkey \\ 2 Department of Architectural Restoration, Faculty of Architecture, İzmir Institute of Technology, Gülbahçe Mahallesi, \\ 35430 Urla-izzmir, Turkey \\ ${ }^{3}$ Department of City and Regional Planning, Faculty of Architecture, İzmir Institute of Technology, Gülbahçe Mahallesi, \\ 35430 Urla-izmir, Turkey \\ ${ }^{4}$ Department of Civil Engineering, Faculty of Engineering, İzmir Institute of Technology, Gülbahçe Mahallesi, 35430 Urla-İzmir, \\ Turkey \\ * Corresponding author, e-mail: funda.gencer@cbu.edu.tr
}

Received: 29 February 2020, Accepted: 20 October 2020, Published online: 13 November 2020

\begin{abstract}
Since ancient times, different techniques have been favoured to provide the integrity of masonry buildings at risk from earthquakes. Earthquake consciousness and determination of related effective techniques have always been a challenging subject. In this study, morphologic characteristics affecting structural resistance of dry-joint masonry towers, and their impact on each other are examined with the help of the statistical analysis. The effectiveness of each characteristic is discussed in relation to the earthquake risk level of the regions to decipher awareness of precautions necessary for structural resistance of dry-joint masonry under earthquake risk in ancient periods.

The methodology includes gathering morphologic data with the conventional site survey techniques of architectural restoration; visual analysis of the dataset; design of hypothetical towers by combining possible characteristics of real towers; quasi-static tilt analysis of hypothetical towers with MsPhysics 1.0.3 software; regression analysis of the collapse limits for different morphologic configurations with EViews 4 software, and the proposition of a vulnerability framework and application of the framework to case studies.

The parameters affecting structural resistance are listed in the order of high to low impact as a staggering ratio, stone depth, ratio between block length and height, proportional relationship between height and length, opening area, number and position and the distribution of header stones. The application of the framework to case studies indicated consciousness awareness of the risk and the taking of precautions against lateral loading of dry-joint masonry in ancient periods.
\end{abstract}

\section{Keywords}

vulnerability, masonry, statistical analysis, quasi-static analysis

\section{Introduction}

Morphologic characteristics affect the structural performance of buildings. In dry-joint masonry buildings, characteristics such as the proportion of building length to height; the geology, size, proportion and organisation of stone blocks, and distribution of openings present variations. In turn, structural resistance of dry-joint masonry buildings with different morphologies present differences under similar earthquake conditions. Several pieces of research have been conducted to examine one or two of the characteristics affecting structural resistance of dry-joint masonry buildings (de Felice, 2011; Foti et al., 2018; Giuffrè, 1996; Jimenez, 2011; Vaculik et al., 2004). The variation in the organisation of blocks is evaluated in the majority of the studies. For example, de Felice (2011) studied stone size and number of headers; Foti et al. (2018) studied masonry pattern, and Giuffrè (1996) studied the usage of header stones between leaves. The organisation of blocks was also examined in relation to material characteristics (Giuffre et al., 1994; Godio et al., 2018; Vaculik, 2012). Vaculik et al. (2004) and Jimenez (2011) studied opening organisation concerning boundary conditions and reinforcement of slenderness. Some of these studies are experimental (Jimenez, 2011; Restrepo Vélez et al., 2014), while some are simulations using computational (Bui et al., 2017; Erdogmus et al., 2020; Gençer et al., 2020; Lemos, 2019; Pulatsu et al., 2016; Pulatsu et al., 2019; Senthivel and 
Lourenço, 2009) or analytical methods (D'Ayala and Speranza, 2003; Vaculik et al., 2004). The majority are experiments with newly designed dry masonry elements, rather than considering historical cases. Moreover, the effectiveness of the characteristics relative to each other has not been evaluated in any of these preliminary studies.

In this study, the focus is ancient dry-joint masonry tower typology. The aim is to determine the impact of each morphologic characteristic on each other so that a practical way of surveying the structural vulnerability of an ancient dry-joint masonry tower under lateral loading can be proposed. Since there are many characteristics to be handled, statistical analysis techniques were considered for evaluation. Thus, the methodology of this study comprises the tools of architectural restoration and civil engineering with those of statistics.

Different statistical analysis methods have been used in architecture and architectural conservation discipline (Carpino, et al., 2017; Gençer, 2019; Kanıt and Baykan, 2020; Serteser and Karadag, 2018). Multiple regression analysis, a statistical technique that analyses the relationship between two or more independent variables and estimates the value of the dependent variable, was used. It has been adapted to different disciplines. Regression analysis is used in different research areas such as the economy (Anghelache and Anghel, 2014; Busu, 2019; Dimian, 2014; Duran and Ferreira-Lopes, 2016; Duran, 2017; Uysal and Aydemir, 2016), medicine (Başgelmez and Yıldız, 2017; Conradetal.,2010; Kaieretal., 2010; Onderand Batigun, 2016; Pervaiz et al., 2017), educational sciences (Pedhazur, 1997; Radhy, 2019; Ünal et al., 2017; Wang et al., 2011; Yavuz et al., 2017), agriculture (Kelechi, 2012; Kuethe and Borchers, 2012) and engineering (Carpino et al., 2017; Chen et al., 2011; Kanit and Baykan, 2020).

The general aim of multiple regression is to understand the relationship between several independent variables and a dependent variable (Pearson and Lee, 1908). The value of the independent variables changes depending on gathered data in the site survey, while the value of the dependent variable only changes in response to the independent variables. With regression analysis, the coefficients and probability of the variables affecting the independent variable and $F$ value (probability) and $R$-squared $\left(R^{2}\right)$ values of the regression model are determined. The $p$-value of the coefficients of variables in regressions determines the significance of variables. We accept the parameters that have less than $5 \% p$-value (probability) as a statistically significant coefficient. The regressions which have higher than $0.75 R$-squared are stated as a more relevant regression (Henseler et al., 2009). This means that variables are accepted as parameters, and their coefficients are statistically very significant.

\section{Experimental process}

First, case study towers in different ancient regions under different earthquake risk were selected with a literature review. These regions are Caria, Pamphylia and Cilicia; they are under high, medium and low earthquake risk, respectively. Secondly, Alinda and Latmos towers in Caria; Perge and Sillyon Towers in Pamphylia, and Gömeç and Sarayın in the Cilicia Region, which have sustained their integrity and authenticity to a great extent, were surveyed with triangulation and running measurements using a laser meter. The measured survey was supported with single image rectification. Thirdly, visual data was classified. In turn, the following characteristic types were determined: six wall profiles, fifteen opening organisations, four ratios between wall height and length. Characteristic types are illustrated in Fig. 1.

In the $5^{\text {th }}$ step, all possible characteristic types were combined and hypothetical towers $(6 \times 4 \times 15=360)$ were modelled (SketchUp (2017), Trimble) and their collapse angles were determined one by one with quasi-static tilt analysis (MSPhysics 1.0.3). MSPhysics is used for the quasi-static tilt analysis simulation based on the equilibrium state. It allows real-time physics simulation of rigid elements where each one can have specific properties such as shape, density and friction (Synytsia, 2017). It is a static, rigid body approach; thus, no stress occurs, and the force transfer between two blocks is uniformly distributed over the contact surface.

In the simulations, friction coefficient and density are taken into consideration, but modulus of elasticity is ignored based on studies in the literature because the displacements due to elastic deformation are negligible (D'Ayala and Speranza, 2003). Based on laboratory analysis, two types of stone were determined: granite and limestone (Gençer, 2019). In the literature studies on the behaviour of dry masonry, density (weight) and coefficient of friction values are critical (Bui et al., 2017; Restrepo Vélez et al., 2014). The friction coefficient of rock stone in masonry change between approximately 0.6 and 0.7 , so there is not a considerable difference between coefficients of rocks (limestone: 0.75 ; granite: 0.6 ) (The Concrete Institute, 1909). The density of materials changes depending on the hardness or softness of the material. Therefore, common density values for stones were accepted (limestone: 2560; granite: $2750 \mathrm{~kg} / \mathrm{m}^{3}$ ) (Colas et al., 2016). 




OPENING TYPES
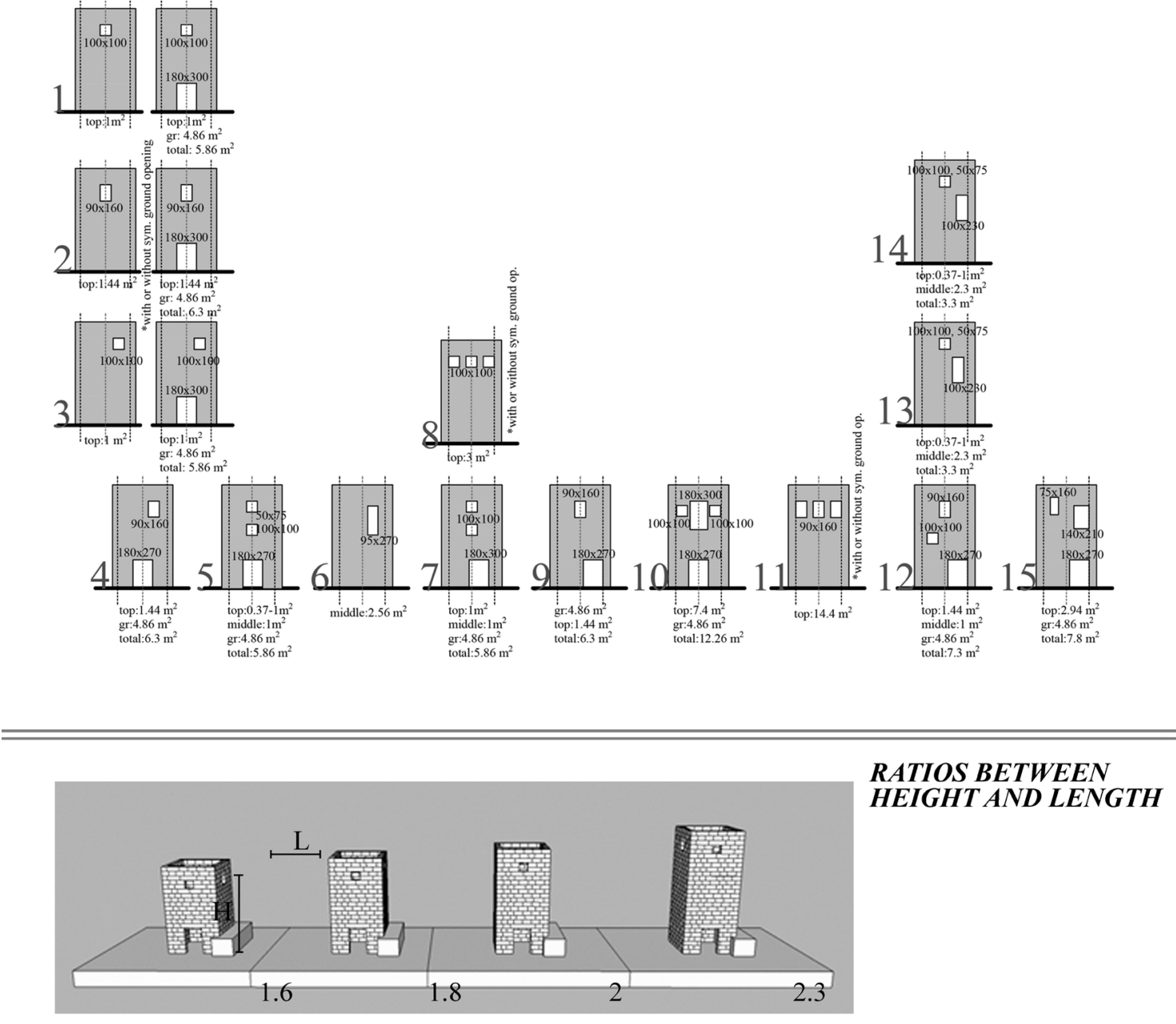

Fig. 1 Wall profile, opening types and $h / l$ ratios 
The collapse angles simulate lateral loading, which resembles earthquake behaviour to some extent. The validity of this analysis was proved with experimental work in the laboratory by tilting the table on which towers out of wooden blocks were placed (Gençer et al., 2020), and the results were supported with a literature review (Restrepo Vélez et al., 2014). Thus, quasi-static tilt analysis was considered as a practical way of understanding the differences in the structural behaviour of dry-joint masonry towers with different morphologies under changing lateral loading. Phases of tilt analysis are illustrated in Fig. 2.

The angle of collapse under lateral loading is the dependent variable. It depends on the variation in morphologic characteristics. The characteristics that affect collapse angle is clarified as the wall profile, opening organisation and proportional relationship between height and length (Table 1). So, these characteristics are the independent variables. The wall profile is affected by the variation in stone depth, the ratio between block length and height, staggering of blocks, which is the ratio between the horizontal distance between joints and the height of the related course; and distribution of headers at their upper portions. Openings are critical when they are positioned at the upper portion of a tower. Thus, the area, number and position of openings have an effect on structural resistance.

In the $6^{\text {th }}$ step, the data set, including only the variables for the characteristics of the hypothetical towers, was dissociated from the whole (Table 2).

In the $7^{\text {th }}$ step, the data set, including the collapse angles as dependent variables and morphologic characteristics as independent variables, was analysed with the help of the Eviews software. Multiple regression analysis helped in predicting the value of the dependent variable $Y$ for given values of independent variables $X_{1}, X_{2}, \ldots, X_{k}$. In general, the multiple regression equation of $Y$ on $X_{1}, X_{2}, \ldots, X_{k}$ is given by Eq. (1) (Eviews, 2017):

$Y=$ constant $+b_{1} X_{1}+b_{2} X_{2}+\cdots \cdots+b_{k} X_{k}$. $b_{1}, b_{2}, b_{3}, \ldots, b_{k}$ are called regression coefficients. $Y$ is the dependent variable. Thus, if $b_{1}=2.5$, then $Y$ increases by 2.5 units when $X_{1}$ is increased by 1 unit. The linear relationship between dependent variables and independent variables are determined before regression analysis. The relation between height and length proportion, and collapse angle within the limits of the real towers shows linearity.

With regression analysis, the coefficients and probability of the variables are determined. Thus, variables were identified as parameters. To compare the parameters with each other, an impact analysis is performed using the standard deviation value and coefficients of each parameter. In this way, the effect of the parameters was compared with each other (Ertekin and Özmen, 2017; Pedhazur, 1997; Ünal et al., 2017; Wang et al., 2011; Yavuz et al., 2017). Impact value $=$ Coefficient of independent $\mathrm{v}$. $\times$ Standard Deviation (Independent v.) /Standard Deviation (Dependent v.)

With the help of the impact values, dominancy of parameters can be determined.

In the $8^{\text {th }}$ step, vulnerability framework is proposed with the help of the impact values of parameters gained by statistical evaluation. The vulnerability was assessed in incremental steps with the help of the impact values of parameters; ranking vulnerability at levels such as very high, high, medium, low, considerably low and critical. Vulnerability rankings are determined for openings at the in-plane position since always the worst case is considered. Finally, the framework is applied to the case study towers.

\section{Results and discussion}

Since the probability of variables is less than $5 \%$, regression analysis is significant. The $F$-Value and their corresponding $p$-value is also another important criterion for the relevancy of the regression. The regressions with lower $p$-value and higher $F$ statistics can be referred
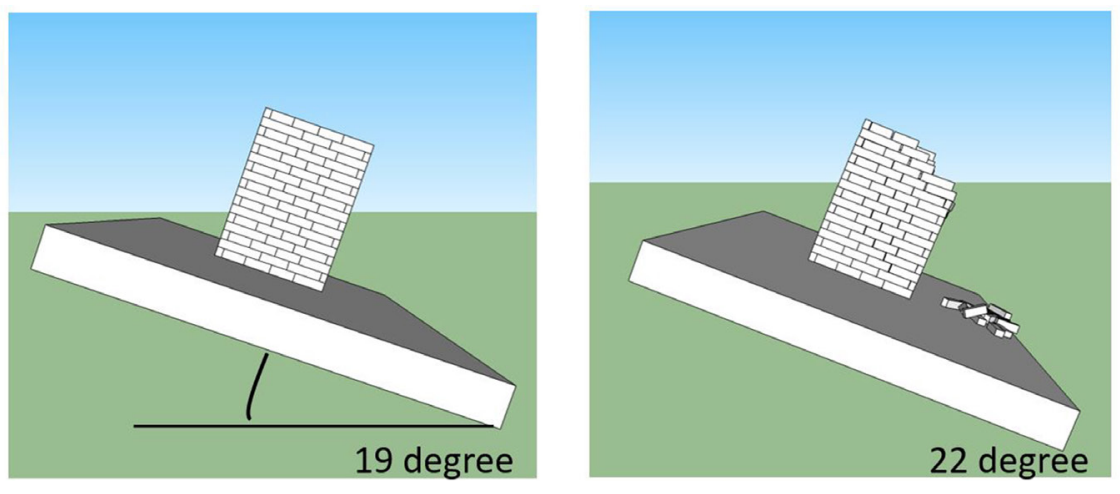

Fig. 2 Tilt analysis in MSPhysics

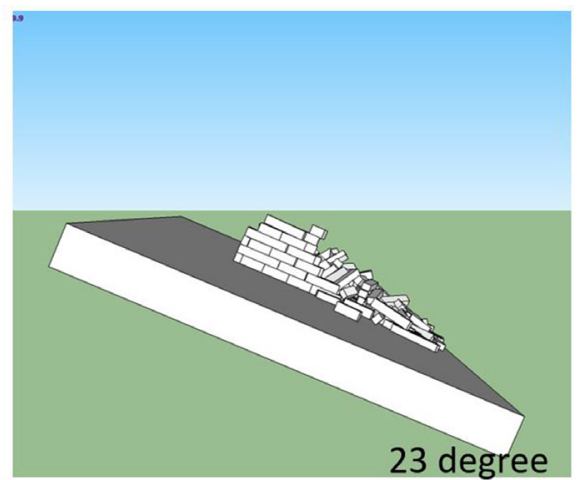


Table 1 Dependent and independent variables of the regression model

\begin{tabular}{|c|c|c|}
\hline $\begin{array}{l}\text { Dependent } \\
\text { variable }\end{array}$ & & Independent variables \\
\hline \multirow{3}{*}{ Collapse angle } & Wall profile & $\begin{array}{ll}\text { - } & \text { Staggering ratio } \\
\text { - } & \text { Ratio between block length and } \\
\text { height } \\
\text { - Stone depth } \\
\text { - } \\
\end{array}$ \\
\hline & Opening & $\begin{array}{l}\text { - Upper opening area } \\
\text { - Upper opening number } \\
\text { - } \quad \text { Upper opening position }\end{array}$ \\
\hline & $\begin{array}{l}\text { Proportional } \\
\text { relationship }\end{array}$ & $\begin{array}{l}\text { - Ratio between height and } \\
\text { length }\end{array}$ \\
\hline
\end{tabular}

Table 2 The data set for regression analysis

\begin{tabular}{|c|c|c|c|c|c|c|c|c|c|}
\hline 㐫 & $\begin{array}{l}\frac{0}{60} \\
\overrightarrow{0} \\
0 \\
0 \\
0 \\
\overline{0} \\
\overline{0} \\
0\end{array}$ & $\lesssim$ & 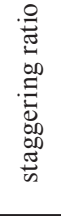 & $\underset{\Xi}{\lesssim}$ &  & $\begin{array}{l}\frac{\bar{\Xi}}{\tilde{J}} \\
\text { d. } \\
\dot{\bar{J}} \\
\stackrel{0}{0}\end{array}$ & $\begin{array}{l}\dot{\Xi} \\
\text { है } \\
\text { 音 } \\
\dot{0}\end{array}$ & $\begin{array}{l}0 \\
: 0 \\
0 \\
0 \\
0 \\
\text { Оे }\end{array}$ & $\begin{array}{l}\widetilde{J} \\
\text { Uँ } \\
\text { Oें }\end{array}$ \\
\hline 1 & 11 & 1.6 & 0.4 & 1.5 & 60 & 0 & 1 & 3 & 1 \\
\hline 2 & 11 & 1.8 & 0.4 & 1.5 & 60 & 0 & 1 & 3 & 1 \\
\hline 3 & 11 & 2 & 0.4 & 1.5 & 60 & 0 & 1 & 3 & 1 \\
\hline 4 & 11 & 2.3 & 0.4 & 1.5 & 60 & 0 & 1 & 3 & 1 \\
\hline 5 & 11 & 1.6 & 0.4 & 1.5 & 60 & 0 & 1 & 3 & 1.4 \\
\hline 6 & 11 & 1.8 & 0.4 & 1.5 & 60 & 0 & 1 & 3 & 1.4 \\
\hline 7 & 11 & 2 & 0.4 & 1.5 & 60 & 0 & 1 & 3 & 1.4 \\
\hline 8 & 11 & 2.3 & 0.4 & 1.5 & 60 & 0 & 1 & 3 & 1.4 \\
\hline 9 & 11 & 1.6 & 0.4 & 1.5 & 60 & 0 & 1 & 1.5 & 1 \\
\hline 10 & 11 & 1.8 & 0.4 & 1.5 & 60 & 0 & 1 & 1.5 & 1 \\
\hline 11 & 11 & 2 & 0.4 & 1.5 & 60 & 0 & 1 & 1.5 & 1 \\
\hline 12 & 11 & 2.3 & 0.4 & 1.5 & 60 & 0 & 1 & 1.5 & 1 \\
\hline . & . & . & . & . & . & . & . & $\cdot$ & . \\
\hline 360 & 11 & 2.3 & 0.4 & 1.5 & 60 & 0 & 2 & 3 & 1 \\
\hline
\end{tabular}

to as more relevant regression. This means that all variables can influence the collapse angle. This indicates strong evidence of parameters (Table 3).

Both $R$-squared $\left(R^{2}\right)$ and Adjusted $R$-squared (adjusted $R^{2}$ ) show the proportion in which the collapse angle is explained through the parameters. $R$-squared value is about $95 \%$. This high percentage indicates that the model explains most of the variability of the response data. Henseler et al. (2009) identify acceptance level of $R^{2}$ values as $75 \%, 50 \%$, and $25 \%$ : substantial, moderate and weak, respectively (Henseler et al., 2009). This shows that the regression model is substantial. The regression result shows that all the coefficients are statistically very significant.

It can be stated that the model that describes the variables affecting structural resistance of dry-joint masonry
Table 3 Statistical analysis results

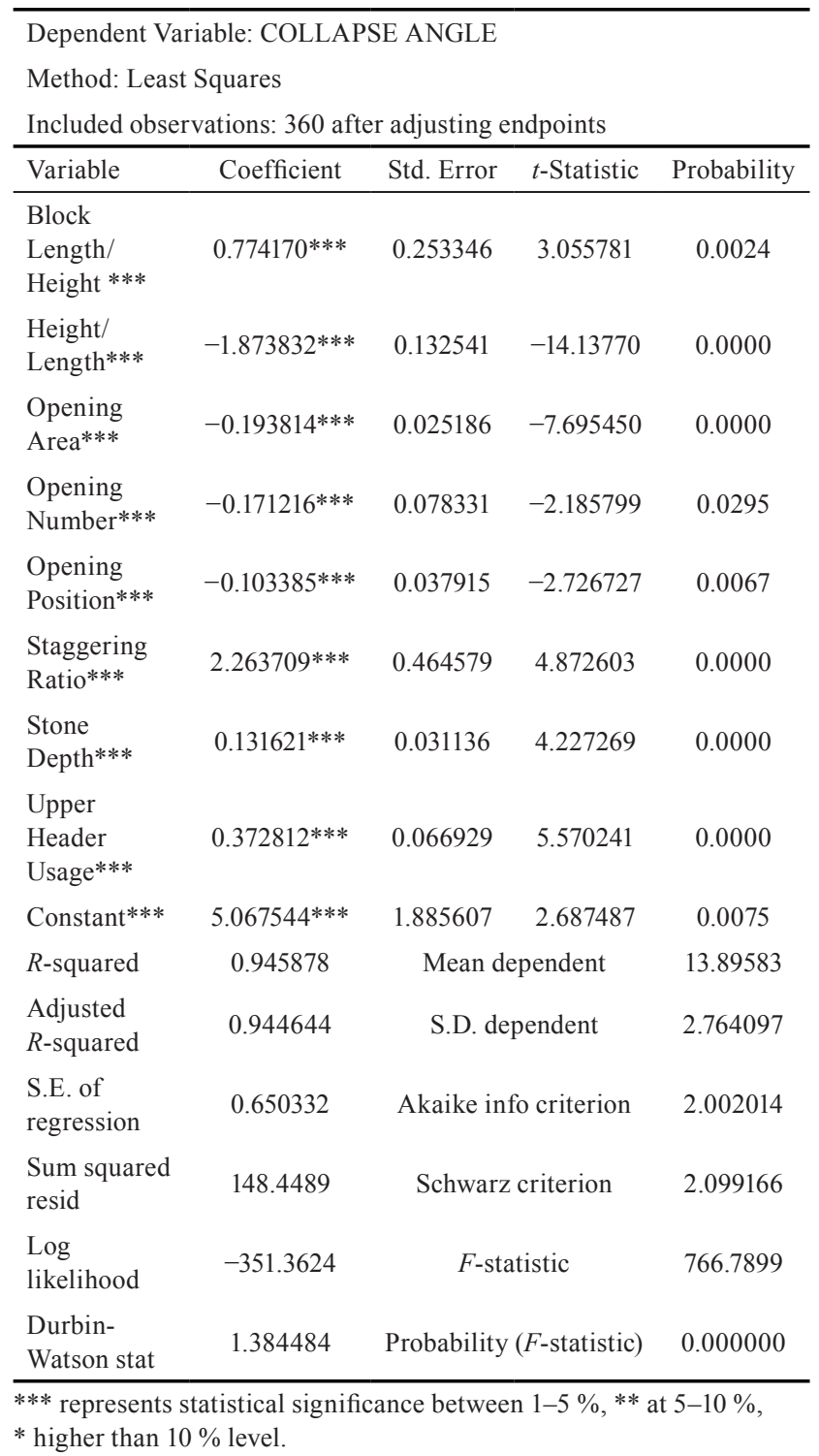

towers can be used to make reliable proposals for the structural vulnerability of dry masonry towers against lateral load. The coefficient of variables that affect structural resistance negatively and positively are determined. However, the parameters cannot be compared because they have different coefficient units. To compare the parameters with each other, impact values of parameters with the same unit were calculated by using the standard deviation value and coefficients of each parameter. While discussing these parameters, intervals of parameters should be taken into consideration (Table 4).

The impact value represents the highest numerical value of the interval of each parameter. When the impact of parameters is listed from their positive impact to negative impact, the parameters providing a considerably positive 
Table 4 Calculation of impact values of coefficients

\begin{tabular}{|c|c|c|c|c|c|}
\hline $\begin{array}{l}\text { Independent } \\
\text { variables }\end{array}$ & 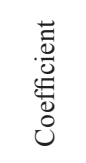 & $\begin{array}{l}\dot{0} \\
\stackrel{D}{\Xi} \\
\dot{0}\end{array}$ & $\begin{array}{l}\dot{\theta} \\
\dot{\theta} \\
\dot{\theta}\end{array}$ & 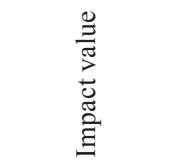 & $\frac{0}{x}$ \\
\hline $\begin{array}{l}\text { Staggering } \\
\text { ratio }\end{array}$ & 2.3 & 0.5312 & 2.76 & 0.44206449 & 4.4 \\
\hline Stone depth & 0.1 & 8.6723 & 2.76 & 0.31374829 & 3.1 \\
\hline$b l / b h$ & 0.8 & 0.8250 & 2.76 & 0.23878369 & 2.4 \\
\hline Upper header & 0.4 & 0.0435 & 2.76 & 0.00629816 & 0.1 \\
\hline Op. number & -0.17 & 0.6541 & 2.76 & -0.04022944 & -0.4 \\
\hline Op. position & -0.1 & 1.1591 & 2.76 & -0.04193755 & -0.4 \\
\hline Op. area & -0.19 & 2.2228 & 2.76 & -0.1527948 & -1.5 \\
\hline$h / l$ & -1.9 & 0.2589 & 2.76 & -0.1780066 & -1.8 \\
\hline
\end{tabular}

impact on resistance are about wall profile; staggering ratio, stone depth and the ratio between block length and height; while the parameters decreasing resistance highly are $h / l$ ratio and opening (Table 5).

With the help of the table, the dominancy of parameters according to their intervals, is discussed when they are combined.

The parameter presenting the highest positive impact is staggering ratio higher than 1.8. Wall profile parameters have three times higher positive impact values than the opening organisation and proportional relationship parameters. This demonstrates that when the highest staggering ratio is combined with any other parameter, it is not affected unless all other parameters of morphologic characteristics are taken with their negative aspects.

Stone depth longer than $75 \mathrm{~cm}$ and block ratio higher than three also provide positive impact. The wall profile parameters that cause the lowest resistance are staggering ratio smaller than 0.4 , stone depth shorter than $60 \mathrm{~cm}$, block ratio smaller than 1.5. Header usage decreases resistance when it is combined with parameters that have the

Table 5 Impact values and intervals of parameters

\begin{tabular}{lccc}
\hline $\begin{array}{l}\text { Analysis } \\
\text { interval }\end{array}$ & Definition & $\begin{array}{c}\text { Numeric } \\
\text { value }\end{array}$ & $\begin{array}{c}\text { Impact } \\
\text { Value }\end{array}$ \\
\hline $0.4-1.8$ & Staggering ratio $(s / h)$ & 1.8 & 4.4 \\
$0.5-0.75 \mathrm{~m}$ & Stone depth & $0.75 \mathrm{~m}$ & 3 \\
$1.5-4$ & Block length/height $(b l / h)$ & 4 & 2 \\
$0-11 \%$ & Distribution of upper headers & $11 \%$ & 0.06 \\
$1-3$ & Upper opening number & 3 & -0.4 \\
$0-3 \mathrm{~m}$ & Upper opening position & 0 & -0.4 \\
$1-5 \mathrm{~m}{ }^{2}$ & An upper opening area & 5 & -1.5 \\
$1.6-2.3$ & Proportional relationship & 2.3 & -1.8 \\
\hline
\end{tabular}

lowest impact; however, it increases resistance when it is combined with parameters that have higher impact values.

The morphologic parameters causing the highest decrease in resistance are an opening size larger than $5 \mathrm{~m}^{2}$ and $h / l$ ratio higher than 2 . These parameters cause a decrease in resistance when they are combined with wall profile parameters, except for the highest impact value as a staggering ratio higher than 1.7 and stone depth higher than $75 \mathrm{~cm}$. If the worst $h / l$ ratio and opening configuration are combined with parameters that have the highest impact, they can decrease resistance.

Morphologic parameters that have minimum negative impact value; $h / l$ ratio between 1.8 and 2 , openings larger than $3 \mathrm{~m}^{2}$, more than 2 in number or close to a corner $(\max 30 \mathrm{~cm})$ cause a decrease in resistance when they are combined with parameters of wall profiles that have impact values of 0.4 and 0 .

Symmetric openings with an area between 1 and $3 \mathrm{~m}^{2}$ and $h / l$ ratios between 1.6 and 1.8 do not decrease resistance with all other positive wall profile parameters.

\section{Proposal for vulnerability assessment}

The vulnerability of ancient dry-joint masonry towers is proposed to be assessed in incremental steps with the help of the impact values of the above-defined parameters; by ranking vulnerability at levels such as high, medium, low, considerably low and critical. Vulnerability rankings are shown in Table 6. Vulnerability rankings are determined for openings at the in-plane position since the worst case is always considered.

Medium vulnerability corresponds to the towers that are constructed within the following limits:

- Staggering ratio higher than 1.7 with stone ratio between 1.5 and 3, stone depth higher than $75 \mathrm{~cm}$ for one leafed wall profiles with opening types larger than $5 \mathrm{~m}^{2}$, and $h / l$ ratios higher than 2 or smaller than 1.3.

- Staggering ratio between 0.6 and 0.8 , stone ratio smaller than 1.5, stone depth shorter than $60 \mathrm{~cm}$ for one or double leafed wall profiles, for all opening types except larger than $5 \mathrm{~m}^{2}$, more than two in number, and maximum $30 \mathrm{~cm}$ from a corner, all $h / l$ ratios except higher than 1.8 or smaller than 1.3.

High vulnerability corresponds to the towers that are constructed within the following limits:

- Staggering ratio between 0.6 and 0.8 , stone ratio smaller than 1.5, stone depth shorter than $60 \mathrm{~cm}$ for one or double leafed wall profiles with opening 
Table 6 Vulnerability assessment framework

\begin{tabular}{|c|c|c|c|c|c|c|}
\hline & & $\begin{array}{c}0.6<s / h \leq 0.8 \\
b l / h \leq 2 \\
\text { header } 11 \%\end{array}$ & $\begin{array}{c}s / h \geq 1.8 \\
3<b l / h \leq 4 \\
\text { header } 11 \%\end{array}$ & $\begin{array}{c}s / h \leq 0.4 \\
b l / h \leq 1.5 \\
\text { stone depth } \leq 60\end{array}$ & $\begin{array}{c}0.6<s / h \leq 0.8 \\
b l / h \leq 2 \\
\text { stone depth } \leq 60\end{array}$ & $\begin{array}{c}s / h \geq 1.8 \\
1.5<b l / h \leq 3 \\
\text { stone depth } \geq 75\end{array}$ \\
\hline \multirow{4}{*}{$1.6 \leq h / l \leq 1.8$} & $\begin{array}{l}\text { Op. number } 1 \text { or } 2 \text {, asy/sym, } \\
1 \leq \text { Area } \leq 3 \mathrm{~m}^{2}\end{array}$ & Medium & C. Low & High & Medium & C. Low \\
\hline & An opening area $\geq 5 \mathrm{~m}^{2}$ & High & C. Low & C. High & High & Low \\
\hline & $\begin{array}{l}\text { Op. number more than } 3 \\
1 \leq \text { Area } \leq 3 \mathrm{~m}^{2}\end{array}$ & High & C. Low & C. High & High & C. Low \\
\hline & $\begin{array}{l}\text { Op. closed to corner }(\max 30 \mathrm{~cm}) \\
1 \leq \text { Area } \leq 3 \mathrm{~m}^{2}\end{array}$ & High & C. Low & C. High & High & C. Low \\
\hline \multirow{4}{*}{$1.8<h / l \leq 2$} & $\begin{array}{l}\text { Op. number } 1 \text { or } 2 \text {, asy/sym, } \\
1 \leq \text { Area } \leq 3 \mathrm{~m}^{2}\end{array}$ & Medium & C. Low & High & Medium & C. Low \\
\hline & An opening area $\geq 5 \mathrm{~m}^{2}$ & High & C. Low & C. High & High & Low \\
\hline & $\begin{array}{l}\text { Op. number more than } 3, \\
1 \leq \text { Area } \leq 3 \mathrm{~m}^{2}\end{array}$ & High & C. Low & C. High & High & C. Low \\
\hline & $\begin{array}{l}\text { Op. closed to corner }(\max 30 \mathrm{~cm}) \\
1 \leq \text { Area } \leq 3 \mathrm{~m}^{2}\end{array}$ & High & C. Low & C. High & High & C. Low \\
\hline \multirow{4}{*}{$h / l>2$} & $\begin{array}{l}\text { Op. number } 1 \text { or } 2, \text { asy/sym, } \\
1 \leq \text { Area } \leq 3 \mathrm{~m}^{2}\end{array}$ & High & C. Low & C. High & High & Low \\
\hline & An opening area $\geq 5 \mathrm{~m}^{2}$ & C. High & Low & Critical & C. High & Medium \\
\hline & $\begin{array}{l}\text { Op. number more than } 3, \\
1 \leq \text { Area } \leq 3 \mathrm{~m}^{2}\end{array}$ & C. High & C. Low & Critical & C. High & Low \\
\hline & $\begin{array}{l}\text { Op. closed to corner }(\max 30 \mathrm{~cm}) \\
1 \leq \text { Area } \leq 3 \mathrm{~m}^{2}\end{array}$ & C. High & C. Low & Critical & C. High & Low \\
\hline
\end{tabular}

* C. defines Considerably.

types larger than $5 \mathrm{~m}^{2}$, more than 2 in number, and maximum $30 \mathrm{~cm}$ in distance to a corner and with $h / l$ ratios between 1.6 and 1.8 .

- Staggering ratio between 0.6 and 0.8 , stone ratio smaller than 1.5 , stone depth shorter than $60 \mathrm{~cm}$ for one or double leafed wall profiles with all opening types except larger than $5 \mathrm{~m}^{2}$, more than 2 in number, and maximum $30 \mathrm{~cm}$ in distance to a corner and with $h / l$ ratios higher than 1.8 or smaller than 1.3 .

- Staggering ratio smaller than 0.4, stone ratio smaller than 1.5 , stone depth shorter than $60 \mathrm{~cm}$ for one leafed wall profiles with all opening types except larger than $5 \mathrm{~m}^{2}$, more than 2 in number, and maximum $30 \mathrm{~cm}$ in distance to a corner at $h / l$ ratios 1.6 and 2 .

Considerably high vulnerability corresponds to the towers that are constructed within the following limits:

- Staggering ratio between 0.6 and 0.8 , stone ratio smaller than 1.5, stone depth shorter than $60 \mathrm{~cm}$ for one or double leafed wall profiles with opening types larger than $5 \mathrm{~m}^{2}$, more than 2 in number, and maximum $30 \mathrm{~cm}$ in distance to a corner at $h / l$ ratios higher than 1.8 or smaller than 1.3 .

- Staggering ratio smaller than 0.4 , stone ratio smaller than 1.5 , stone depth shorter than $60 \mathrm{~cm}$ for one leafed wall profiles with all types larger than $5 \mathrm{~m}^{2}$, more than 2 in number, and maximum $30 \mathrm{~cm}$ in distance to a corner and with $h / l$ ratios between 1.8 and 2 .

- Staggering ratio smaller than 0.4, stone ratio smaller than 1.5, stone depth shorter than $60 \mathrm{~cm}$ for one leafed wall profiles with all opening types except larger than $5 \mathrm{~m}^{2}$, more than 2 in number, and maximum $30 \mathrm{~cm}$ in distance to a corner and with $h / l$ ratios higher than 2 or smaller than 1.3.

Critical vulnerability corresponds to the towers that are constructed within the following limits:

- Staggering ratio smaller than 0.4, stone ratio smaller than 1.5, stone depth shorter than $60 \mathrm{~cm}$ for one leafed wall profiles with all opening types larger than $5 \mathrm{~m}^{2}$, more than 2 in number, and closed maximum $30 \mathrm{~cm}$ in distance to a corner at $h / l$ ratios higher than 2 or smaller than 1.3 .

\section{Vulnerability assessment of case studies}

First, the earthquake risk in the environs of the case studies in terms of frequency and severity are presented by examining earthquake history. The vulnerability framework is applied to case studies. Finally, a preliminary risk assessment against lateral loading is carried out. 


\subsection{Towers in Caria}

Alinda and Latmos Towers in Caria are approximately $70 \mathrm{~km}$ from each other. This region is under high earthquake threat due to extremely high ground acceleration (AFAD, 2018). In a $100 \mathrm{~km}$ proximity of the case studies, 180-190 earthquakes have been recorded from 1900 until the present. In the environs of Latmos, 141 earthquakes have taken place between magnitude 4 and 5 . Between magnitudes 5 and 6 , there have been 34 and between 6 and 7, 8 earthquakes. In the environs of Alinda, between magnitudes 4 and 5, there have been 146 earthquakes, and between 5 and 6, 36 earthquakes; there have been 7 magnitude 6-7 earthquakes. From ancient periods, there are no recorded earthquakes higher than magnitude 6 within approximately $100 \mathrm{~km}$ of the area. Earthquakes higher than magnitude 7 are approximately $600 \mathrm{~km}$ away from the area in the ancient period (BDTIM, 2018).

\subsubsection{Vulnerability of Alinda Tower}

Alinda Tower has low vulnerability with the help of the characteristics of its wall profile, although the weakness of $h / l$ ratio and opening organisation increase vulnerability. It has a high staggeringly ratio (higher than 1.8), and the ratio between block length and height is higher than 4 . Since the walls are composed of leaves, stone depth is also small $(45-50 \mathrm{~cm})$; however, these leaves are connected with header stones.

Although the tower has the weakest opening organisation (one large sized, $5 \mathrm{~m}^{2}$ ) and the north-western facade has a high $h / l$ ratio (2.3), wall profile characteristics provide advantages against the weaknesses of the other morphologic characteristics.Control of vulnerability of the large-sized openings and high facade should be achieved with appropriate measures of intervention.

Diagonal stepped cracking is observed above and below the openings at the south-western, south-eastern, and north-eastern facades today. Characteristic and failures of the tower are shown in Fig. 3.

\subsubsection{Vulnerability of Latmos Tower}

Latmos tower has high vulnerability due to the weakness of the wall profile and opening organisation. Although walls are composed of leaves connected with headers, the small staggering ratio (0.8) and medium ratio between stone lengths and height (2.4) increase vulnerability. Asymmetrical openings adjacent to the corner also increase vulnerability. $H / l$ ratio (1.7) is ideal for vulnerability. Control of the weakness stemming from the original wall profile should be achieved with appropriate measures of intervention.

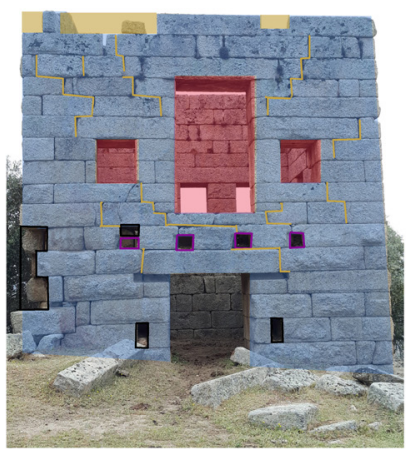

Parameters effecting vulnerability Parameters decreasing

vulnerability
Wall profile Parameters increasing vulnerability Opening

(a)

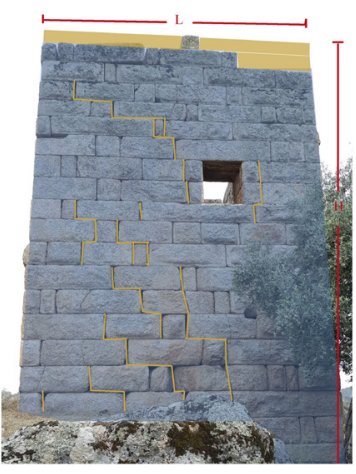

Failure types

Failures which are likely to be caused by lateral loading Crack

Collapse

Failures which are likely to be caused by vandalism $\square$ Removal of blocks Crack

Missing elements

$\square$ Wooden beams

(b)
Fig. 3 Existing failures of Alinda Tower; northern (a) and southern (b) facades

Today, the tower conserves its integrity; however, there are diagonal cracks at upper parts of walls at the northern façade. Characteristic and failures of the tower are shown in Fig. 4.

\subsection{Towers in Cilicia}

Gömeç and Sarayın Towers in the Cilicia Region are approximately $2 \mathrm{~km}$ away from each other. This region is under low earthquake threat due to low ground acceleration (AFAD, 2018). Within $100 \mathrm{~km}$ of the surrounding area, 17 earthquakes have been recorded from 1900 until now: between magnitude 4 and 5, 12 earthquakes have been recorded, and between 5 and 6, 5 earthquakes. In ancient periods, recorded earthquakes have been between magnitude 6 and 7, approximately $350 \mathrm{~km}$ away from the area. There has been one recorded earthquake higher than 7 in Cilicia Region in 1268 (BDTİM, 2018).

\subsubsection{Vulnerability of Gömeç Tower}

Gömeç Tower has considerably high vulnerability due to its wall profile characteristics and $h / l$ ratio, although it has symmetrical small-sized openings. It has a small staggering ratio (0.4), small ratio between stone length and height (1.5) and narrow stone depth $(60 \mathrm{~cm})$, and the $h / l$ ratio is 2.3. Control of the weakness stemming from the original wall profile and high $h / l$ ratio should be achieved with appropriate measures of intervention. 


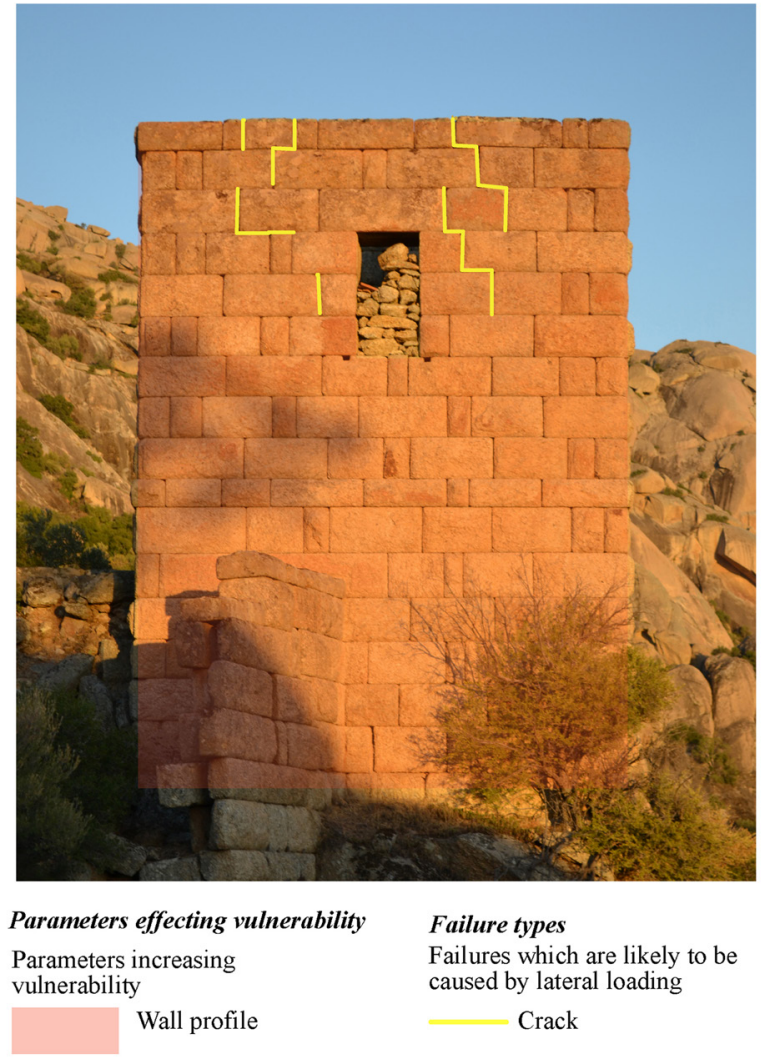

Fig. 4 Existing failures of Latmos Tower; northern façade

The joints of the upper parts and upper openings of the tower are filled with mortar and stone blocks. This may be a latter intervention after a possible failure. Therefore, any sign of structural failure cannot be traced at present. Characteristic and failures of the tower are shown in Fig. 5.

\subsubsection{Vulnerability of Sarayın Tower}

Sarayin Tower has medium vulnerability. It has a small staggering ratio (0.6-0.8), medium ratio between stone length and height (2) and short stone depth $(60 \mathrm{~cm})$. Symmetrical small-sized openings and $h / l$ ratio (2) do not affect vulnerability.Control of the weakness stemming from the original wall profile should be achieved with appropriate measures of intervention.

The present situation of the tower does not give information on its structural problems, joints of upper parts and upper openings of the tower are filled with mortar and stone blocks. The upperparts are thought to have been constructed later since the dimensions of blocks are smaller at the upper parts. This may be a latter intervention after a possible failure. Characteristic and failures of the tower are shown in Fig. 6.

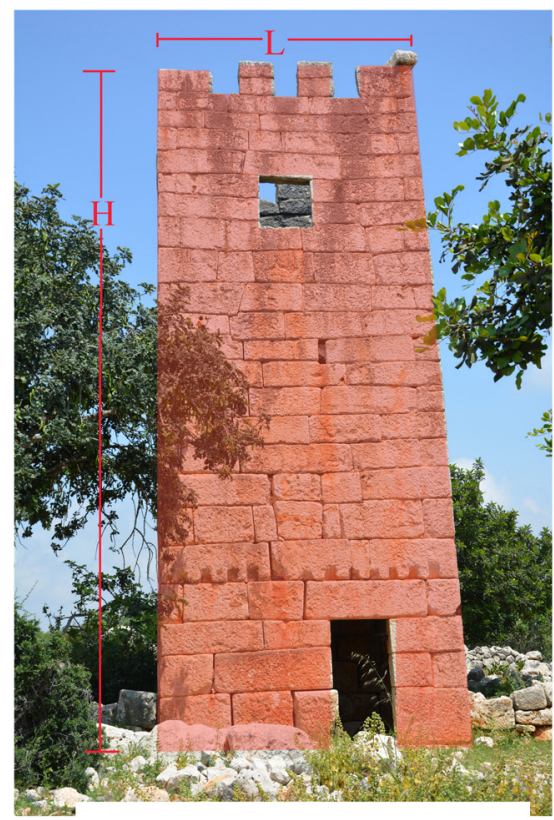

Parameters effecting vulnerability

Parameters increasing vulnerability

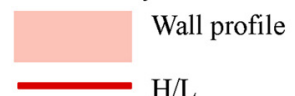

Fig. 5 Present situation of Gömeç Tower; northern façade

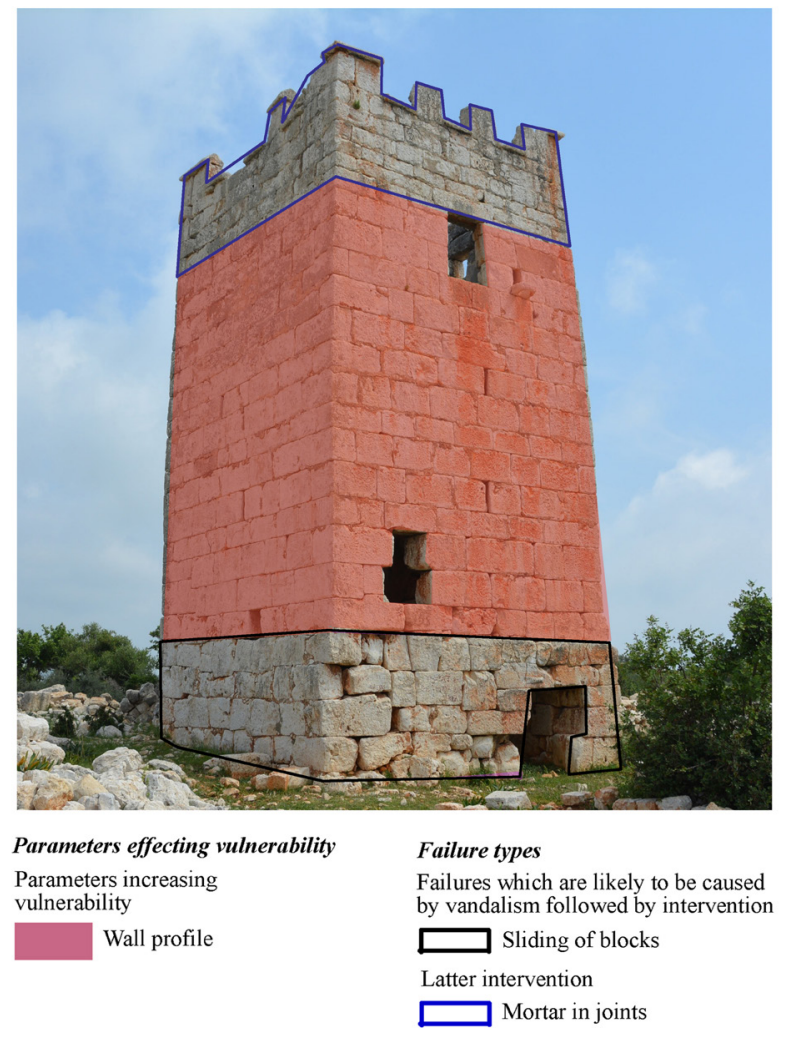

Fig. 6 Present situation of Sarayın Tower 


\subsection{Towers in Pamphylia}

Perge and Sillyon Towers in the Pamphylia Region are approximately $18 \mathrm{~km}$ away from each other. This region is under high earthquake threat due to high ground acceleration (AFAD, 2018). Within $100 \mathrm{~km}$ of the surrounding area, 125 earthquakes have been recorded from 1900 until today. In the surroundings of Latmos, between magnitude 4 and 5, there have been 105 earthquakes. Between 5 and 6, 19 earthquakes and between 6 and 7, one earthquake (BDTIM, 2018).

\subsubsection{Vulnerability of Perge Tower}

Perge Tower has high vulnerability due to both its wall profile and opening characteristics. At the lower level, the staggering ratio decreases to 0.3 , while it changes between 0.6 and 1 at the upper level. Ratio between stone length and height is medium (2); however, the depth of stones is $60 \mathrm{~cm}$. As well as weaknesses of the wall profile, the tower is composed of three upper medium-sized $(90 \times 160 \mathrm{~cm})$ symmetrical openings on each facade. $H / L$ ratio does not affect vulnerability ( $h / l: 2)$. Control of the weakness stemming from the original wall profile intervention and opening characteristics should be achieved with appropriate measures.

Today, the western facade wall of the tower is not present, and the related side walls were demolished partially as well. Characteristic and failures of the tower are shown in Fig. 7.

\subsubsection{Vulnerability of Sillyon Tower}

Sillyon tower has considerably low vulnerability with the help of the characteristics of the wall profile and ideal $h / l$ ratio ( $h / l$ between 1.6 and 1.8 ). It has a high



Fig. 7 Present situation of Perge Tower staggering ratio (average 1.7) and high block length and height ratio (3) with the help of the blocks $25 \mathrm{~cm}$ in height, in each row at the upper parts. One leafed wall has also longer stone depth $(75 \mathrm{~cm})$. The opening adjacent to the corner $(105 \times 300 \mathrm{~cm})$ at western facade increases vulnerability. Control of the weakness stemming from the original corner opening should be achieved with appropriate intervention measures.

Today, in the upper parts, diagonal cracks are observed, but the main problem of the tower is vertical cracks due to settlement. Characteristic and failures of the tower are shown in Fig. 8.

\section{Conclusion}

The study clarifies the parameters that affect the structural resistance of ancient dry-joint masonry towers under lateral loading. The authentic qualities of these parameters should be sustained in conservation work. The parameters

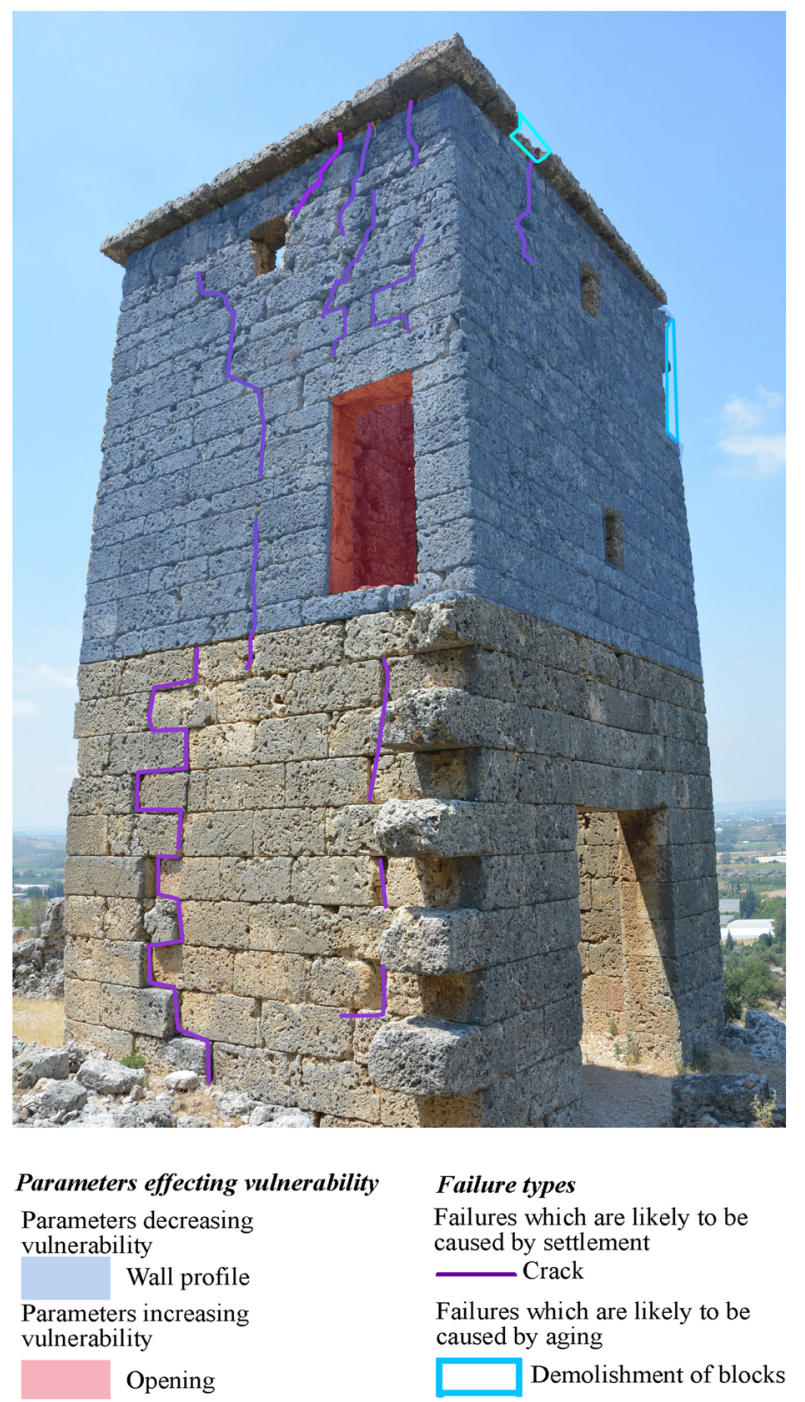

Fig. 8 Present situation of Sillyon Tower; northern and western facades 
affecting structural resistance are listed in the order of high impact to low as the staggering ratio, stone depth, ratio between block length and height, proportional relationship between height and length, opening area, number and position and even distribution of header stones. These results show that primary parameters affecting structural resistance are about the organisation of blocks, while parameters of building morphology such as heightlength relations and opening areas are secondary parameters. It was revealed that parameters should always be considered in relation to each other.

Consequently, with the interpretation of results, a framework composed of vulnerability rankings was proposed for the assessment of the dry-joint masonry towers. This understanding of the structural vulnerability paves the way to the correct planning of related consolidation

\section{References}

AFAD "Türkiye Deprem Tehlike Haritası" (Turkey Earthquake Hazard Map), [online] Available at: https://www.afad.gov.tr/tr/26539/YeniDeprem-Tehlike-Haritasi-Yayimlandi [Accessed: 05 March 2018] (in Turkish)

Anghelache, C., Anghel, M. G. (2014) "Using the Regression Model in the Analysis of Financial Instruments Portfolios", Procedia Economics and Finance, 10, pp. 324-329. https://doi.org/10.1016/S2212-5671(14)00308-6

Başgelmez, Ş., Yıldız, M. (2017) "Cigarette Consumption and Related Factors in Schizophrenia, Schizoaffective Disorder and Delusional Disorder", The Journal of Psychiatry and Neurological Sciences, 30, pp. 233-242.

https://doi.org/10.5350/DAJPN2017300307

BDTİM "Deprem tarihçesi" (History of Earthquake), [online] Available at: http://www.koeri.boun.edu.tr/sismo/2/son-depremler/debrembilgi-sistemi/\# [Accessed: 05 March 2018] (in Turkish)

Bui, T. T., Limam, A., Sarhosis, V., Hjiaj, M. (2017) "Discrete element modelling of the in-plane and out-of-plane behaviour of dryjoint masonry wall constructions", Engineering Structures, 136, pp. 277-294.

https://doi.org/10.1016/j.engstruct.2017.01.020

Busu, M. (2019) "Measuring the Renewable Energy Efficiency at the European Union Level and Its Impact on $\mathrm{CO}_{2}$ Emissions", Processes, 7(12), Article Number: 923. https://doi.org/10.3390/pr7120923

Carpino, C., Bruno, R., Arcuri, N. (2017) "Statistical analysis of the heating demand in residential buildings located in Mediterranean climate and proposals for refurbishment", Energy Procedia, 133, pp. 16-27. https://doi.org/10.1016/j.egypro.2017.09.365

Chen, M., Li, Q. M., Peng, C. Q. (2011) "Empirical Analysis on the Construction Workers' Contribution to Chinese Construction Industry Economic Growth and Sharing of Economic Gain", Applied Mechanics and Materials, 71-78, pp. 296-299. https://doi.org/10.4028/www.scientific.net/AMM.71-78.296 interventions in the future. If this framework is combined with data about the frequency and intensity of previous earthquakes, risk assessment can be carried out.

Application of the framework on case study towers demonstrated that towers under high earthquake threat were designed with strong parameters such as high staggering ratio, long stone depth or high block ratio, while there is no precaution against lateral loading in the towers under minimum earthquake risk. Precautions preferred in the construction of ancient towers prove that there was an awareness of the earthquake risk status of their sites.

\section{Acknowledgement}

This study has been supported by the Scientific Research Project Department of İzmir Institute of Technology within the scope of the project, 2016G_IYTE83.

Colas, A. S., Garnier, D., Morel, J. C., Ciblac, T., O'Neill, C. (2016) "Cross curves of stability for drystone retaining wall design", In: Modena, C., da Porto, F., Valuzzi, M. R. (eds.) Brick and Block Masonry, CRC Press, London, UK, pp. 165-170. https://doi.org/10.1201/b21889

Conrad, A., Klaus, K., Frank, U., Dettenkofer, M. (2010) "Are short training sessions on hand hygiene effective in preventing hospital-acquired MRSA? A time-series analysis", American Journal of Infection Control, 38(7), pp. 559-561. https://doi.org/10.1016/j.ajic.2009.10.009

D'Ayala, D. F., Speranza, E. (2003) "Definition of Collapse Mechanisms and Seismic Vulnerability of Historic Masonry Buildings", Earthquake Spectra, 19(3), pp. 479-509. https://doi.org/10.1193/1.1599896

de Felice, G. (2011) "Out-of-Plane Seismic Capacity of Masonry Depending on Wall Section Morphology", International Journal of Architectural Heritage: Conservation, Analysis, and Restoration, 5(4-5), pp. 466-482. https://doi.org/10.1080/15583058.2010.530339

Dimian, G. C. (2014) "Labour Market and Educational Mismatches in Romania", Procedia Economics and Finance, 10, pp. 294-303. https://doi.org/10.1016/S2212-5671(14)00305-0

Duran, H. E., Ferreira-Lopes, A. (2016) "Determinants of co-movement and of lead and lag behavior of business cycles in the eurozone", International Review of Applied Economics, 32(2), pp. 255-282. https://doi.org/10.1080/02692171.2016.1249830

Duran, H. E. (2017) "Bölgesel İstihdam Dalgalanmalarının Şiddeti, Sebep ve Sonuçları: Türkiye Örneği" (Regional Employment Volatility-Causes and Consequences: The Case of Turkey), Megaron, 12(2), pp. 280-291. (in Turkish) https://doi.org/10.5505/megaron.2017.52244

Erdogmus, E., Pulatsu, B., Gaggioli, A., Hoff, M. (2020) "Reverse Engineering a Fully Collapsed Ancient Roman Temple through Geoarchaeology and DEM", International Journal of Architectural Heritage: Conservation, Analysis, and Restoration. https://doi.org/10.1080/15583058.2020.1728593 
Ertekin, P., Özmen, D. (2017) "Bir Üniversite Hastanesinde Çalısan Hemsirelerde İse Yabanc1lasmayı Yordayan Degiskenlerin Incelenmesi" (Identification of the Variables Which Predict Alienation from Work in Nurses Who are Studying at a University Hospital), Hemşirelikte Eğitim ve Araştirma Dergisi, 14(1), pp. 25-30. (in Turkish) http://doi.org/10.5222/HEAD.2017.025

Eviews (2017) "Estimating A Regression Model", (Last Modified October 25), [computer program] Available at: http://www.eviews. com/help/helpintro.html\#page/content/demoestimating_a_ Regression_Model.html [Accessed: 24 January 2019]

Foti, D., Vacca, V., Facchini, I. (2018) "DEM modeling and experimental analysis of the static behavior of a dry-joints masonry cross vaults", Construction and Building Materials, 170, pp. 111-120. https://doi.org/10.1016/j.conbuildmat.2018.02.202

Gençer, F. (2019) "Structural Vulnerability of Ancient Dry Masonry Towers under Lateral Loading", PhD Dissertation, Izmir Institute of Technology.

Gençer, F., Hamamcioğlu-Turan, M., Aktaş, E. (2020) "Helenistik kulelerde yanal yüke ilişkin düzlem içi ve düzlem dışı duvar davranışının duvar profilleri ve açıklık tiplerine bağlı olarak incelenmesi" (Investigation of in-plane and out-of-plane wall behavior related to lateral loading depending on wall profiles and opening types in Hellenistic Towers), Journal of the Faculty of Engineering and Architecture of Gazi University, 35(1), pp. 241-254. (in Turkish) https://doi.org/10.17341/gazimmfd.458555

Giuffre, A., Pagnoni, T., Tocci, C. (1994) "In-plane Seismic Behavior of Historical Masonry Walls", [online] Available at: http://www.hms. civil.uminho.pt/ibmac/1994/263.pdf [Accessed: 05 March 2018]

Giuffrè, A. (1996) "A Mechanical Model for Statics and Dynamics of Historical Masonry Buildings", In: Petrini, V., Save, M. (eds.) Protection of the Architectural Heritage Against Earthquakes, Springer-Verlag, Vienna, Austria, pp. 71-152. https://doi.org/10.1007/978-3-7091-2656-1_4

Godio, M., Stefanou, I., Sab, K. (2018) "Effects of the dilatancy of joints and of the size of the building blocks on the mechanical behavior of masonry structures", Meccanica, 53(7), pp. 1629-1643. https://doi.org/10.1007/s11012-017-0688-z

Henseler, J., Ringle, C. M., Sinkovics, R. R. (2009) "The use of partial least squares path modeling in international marketing", Advances in International Marketing, 20, pp. 277-319. http://doi.org/10.1108/S1474-7979(2009)0000020014

Jimenez, D. D. (2011) "Empirical Analysis of Masonry Walls: Structural Design and Seismic Reinforcement through Tilting Experiments", PhD Dissertation, Massachusetts Institute of Technology.

Kaier, K. B., Meyer, E., Dettenkofer, M., Frank, U. (2010) "Epidemiology meets econometrics: using time-series analysis to observe the impact of bed occupancy rates on the spread of multidrug-resistant bacteria", Journal of Hospital Infection, 76(2), pp. 108-113. https://doi.org/10.1016/j.jhin.2010.04.010

Kanıt, R., Baykan, U. N. (2020) "Bina Yaklaşık Maliyetinin Çoklu Doğrusal Regresyon ile Belirlenmesi" (Determination of Approximate Cost of Buildings with Multiple Linear Regression Analyses), Politeknik Dergisi, 7(4), pp. 359-367. [online] Available at: $\quad$ https://dergipark.org.tr/en/download/article-file/384419 [Accessed: 20 February 2020] (in Turkish)
Kelechi, A. C. (2012) "Regression and Principal Component Analyses: A Comparison Using Few Regressors", American Journal of Mathematics and Statistics, 2(1), pp. 1-5. http://doi.org/10.5923/j.ajms.20120201.01

Kuethe, T. H., Borchers, A. (2012) "Farmland Assessment Through Multiple Regression Analysis", Journal of Extension, 50(3), [online] Available at: https://joe.org/joe/2012june/tt3.php [Accessed: 23 February 2020]

Lemos, J. V. (2019) "Discrete Element Modeling of the Seismic Behavior of Masonry Construction", Buildings, 9(2), Article Number: 43. https://doi.org/10.3390/buildings 9020043

Onder, M., Batigun, A. D. (2016) "Premature and Normal Menopause: An Evaluation in Terms of Stress, Marital Adjustment and Sex Roles", The Journal of Psychiatry and Neurological Sciences, 2(29), pp. 129-138. https://doi.org/10.5350/DAJPN2016290204

Pervaiz, R., Tulay, P., Faisal, F., Serakınc1, N. (2017) "Incidence of cancer in the Turkish Republic of Northern Cyprus", Turkish Journal of Medical Sciences, 47, pp. 523-530. https://doi.org/10.3906/sag-1510-145

Pedhazur, E. J. (1997) "Multiple Regression in Behavioral Research: Explanation and Prediction", Wadworth, New York, NY, USA.

Pearson, K., Lee, A. (1908) "On the Generalised Probable Error in Multiple Normal Correlation", Biometrika, 6(1), pp. 59-68. https://doi.org/10.1093/biomet/6.1.59

Pulatsu, B., Bretas, E. M., Lourenco, P. B. (2016) "Discrete element modeling of masonry structures: Validation and application", Earthquakes and Structures, 11(4), pp. 563-582. https://doi.org/10.12989/eas.2016.11.4.563

Pulatsu, B. Erdogmus, E. Bretas, E. M., Lourenço, P. B. (2019) "In-Plane Static Response of Dry-Joint Masonry Arch-Pier Structures", In: AEI 2019: Integrated Building Solutions - The National Agenda, Reston, VA, USA, pp. 240-248. https://doi.org/10.1061/9780784482261.028

Radhy, Z. H. (2019) "Application of Multiply Regression Linear Model and New Technology Method in Estimating Learning and Education of Students", International Electronic Journal of Mathematics Education, 14(1), pp. 87-90.

https://doi.org/10.12973/iejme/3978

Restrepo Vélez, L. F., Magenes, G., Griffith, M. C. (2014) "Dry Stone Masonry Walls in Bending-Part I: Static Tests", International Journal of Architectural Heritage: Conservation, Analysis, and Restoration, 8(1), pp. 1-28. https://doi.org/10.1080/15583058.2012.663059

Senthivel, R., Lourenço, P. B. (2009) "Finite element modelling of deformation characteristics of historical stone masonry shear walls", Engineering Structures, 31(9), pp. 1930-1943. https://doi.org/10.1016/j.engstruct.2009.02.046

Serteser, N., Karadag, I. (2018) "Design for improving pedestrian wind comfort: a case study on a courtyard around a tall building", Architectural Science Review, 61(6), pp. 492-499. https://doi.org/10.1080/00038628.2018.1492899

Synytsia, A. "MSPhysics 1.0.3 (16 October 2017)", [computer program] Available at: https://sketchucation.com/forums/viewtopic. php? $\mathrm{f}=323 \& \mathrm{t}=56852 \&$ start $=660$ [Accessed: 24 January 2019] 
The Concrete Institute (1909) "Transactions and Notes: Volume 1-2", The University of Chicago, Chicago, USA.

Trimble "SketchUp (2017)", [computer program] Available at: https:// www.sketchup.com/node/551 [Accessed: 03 October 2020]

Uysal, D., Aydemir, E. E. (2016) "Türkiye'de Yükseköğretim Kavramı ve Yükseköğretimin İstihdam ve Ekonomiye Etkisinin Analizi" (Concept of Higher Education and Analysis of Impact of Higher Education on Employment and Economy in Turkey), Selçuk Üniversitesi Sosyal Bilimler Dergisi, 35, pp. 275-284. [online] Available at: http://dergisosyalbil.selcuk.edu.tr/susbed/article/ view/1251 [Accessed: 23 February 2020] (in Turkish)

Ünal, F., Tarhan, S., Çürükvelioğlu Köksal, E. (2017) "Toplumsal Cinsiyet Algısını Yordamada Cinsiyet, Sınıf, Bölüm ve Toplumsal Cinsiyet Oluşumunun Rolü" (The Role of Gender, Grade, Department and Socialization of Gender Norms in Predicting Perception of Gender), Bartin University Journal of Faculty of Education, 6(1), pp. 227-236. (in Turkish) https://doi.org/10.14686/buefad.287496

Vaculik, J., Griffith, M., Hogarth, B., Todd, J. (2004) "Out-of-Plane Flexural Response Tests Using Dry-Stack Masonry", In: Australian Earthquake Engineering Society Conference, Mt Gambier, South Australia, Paper number: 18. [online] Available at: http://hdl. handle.net/2440/29276 [Accessed: 03 October 2020]
Vaculik, J. (2012) "Unreinforced Masonry Walls Subjected to OutOf-Plane Seismic Action", PhD Dissertation, The University of Adelaide.

Wang, W., Liu, D. Q., Liu, J. (2011) "On the System of Multiple Linear Regression of Higher Education Tuition in China", Advanced Materials Research, 211-212, pp. 752-755.

https://doi.org/10.4028/www.scientific.net/AMR.211-212.752

Yavuz, H. Ç., Demirtaşlı, R. N., Yalçın, S., İlgün Dibek, M. (2017) "Türk Öğrencilerin TIMSS 2007 ve 2011 Matematik Başarısında Öğrenci ve Öğretmen Özelliklerinin Etkileri" (The Effects of Student and Teacher Level Variables on TIMSS 2007 and 2011 Mathematics Achievement of Turkish Students), Eğitim ve Bilim, 42(189), pp. 27-47. (in Turkish)

https://doi.org/10.15390/EB.2017.6885 